\title{
EVALUASI PELAKSANAAN KURIKULUM TINGKAT SATUAN PENDIDIKAN (SUATU EVALUASI PELAKSANAAN KTSP PADA SMP NEGERI 37 JAKARTA)
}

Oleh : Ismul Bathni S, ST, M.Pd.

\author{
Dosen Prodi D-III Sekretari/Adm. Perkantoran Universitas Pamulang \\ ismul.bat@gmail.com
}

\begin{abstract}
ABSTRAK
Evluasi Pelaksanaan Kurikulum Tingkat Satuan Pendidikan (KTSP). Suatu Evaluasi tentang pelaksanaan KTSP di SMP Negeri 37 Jakarta. Evalusai ini memfokuskan pada landasan formal kurikulum (KTSP) yang disusun oleh sekolah (konteks), kesiapan pejabat sekolah, guru dan siswa, sarana prasarana, ketersediaan informasi, bahan ajar, dan pembiayaan dapat mendukung pelaksanaan KTSP (input), pelaksanaan kegiatan sekolah dalam proses pembelajaran implementasi KTSP telah dijalankan (proses), pelaksanaan program telah dijalankan dan prestasi belajar, kepribadian siswa, dan tujuan-tujuan penerapan KTSP telah tercapai (Produk). Penelitian ini merupakan penelitian kualitatif, peneliti menggunakan model strategi analisis deskriptif analitik, dari hasil pengamatan secara langsung peneliti mendeskripsikan data yang diperoleh yang selanjutnya dipergunakan untuk menarik kesimpulan berupa kategorisasi. Data kualitatif diolah dengan menggunakan statistik deskriptif sehingg didapat rata-rata, simpangan baku, distribusi frekwensi, median, modus , presentil dan grafik sehingga diketahui kelemahan dan kelebihan atau hal-hal yang perlu diperhatikan sehingga dapat dipersentasi, kalkulasi dan kategorisasi. Hasil evaluasi menunjukkan bahwa: Pertama, Kurikulum yang disusun telah sesuai dengan landasan dan petunjuk yang telah ditetapkan. Visi dan Misi Sekolah setelah melalui analisis landasan hukum dan pendapat masyarakat telah sesuai, Struktur kurikulum, muatan kurikulum, pengaturan beban belajar, ketuntasan belajar, kalender pendidikan telah sesuai dengan landasan hukum yang berlaku. Kedua Kebijakan dan keputusan pejabat sekolah berkaitan dengan persiapan KTSP telah memadai dan mendukung terlaksananya Kurikulum tingkat satuan pendidikan (KTSP), kompetensi guru cukup memadai dan perlu ditingkatkan, informasi, prasarana dan biaya telah memadai dalam mendukung terlaksananya KTSP. Ketiga, Kegiatan guru dan siswa telah sesuai dengan program kurikulum yang telah disusun, proses pembelajaran telah sesuai dengan program, kegiatan muatan lokal dan pengembangan diri telah berjalan sesuai dengan program kurikulum yang telah disusun, perlunya meningkatkan ketersediaan fungsi muatan lokal yang berfungsi untuk mengembangkan kompetensi siswa terpenuhi, Beban belajar siswa telah sesuai dengan program. Keempat Prestasi belajar siswa setelah proses pembelajaran tidak mengalami peningkatan, dan lulusan siswa dalam melanjutkan kejenjang yang lebih tinggi telah mecapai target. Hasil evaluasi ini memberikan gambaran tentang konteks, masukan, proses dan produk dari program kurikulum yang disusun oleh sekolah telah sesuai dengan peraturan yang berlaku, selanjutnya diharapkan dapat menjadi rujukan perbaikan dan pengembangan oleh berbagai pihak dalam pengambilan kebijakan yang berorientasi pada perbaikan secara berkesinambungan sehingga kualitas pendidikan indonesia dapat ditingkatkan.
\end{abstract}

Kata Kunci : KTSP, Evaluasi, Kurikulum 


\section{PENDAHULUAN}

\section{Latar belakang Masalah}

Dasar dari rencana-rencana dan isi suatu pedidikan adalah tujuan pendidikan, dalam bukunnya "Curriculum Development Theory and Practice" mengartikan kurikulum sebagai a plan for learning, yakni sesuatu yang direncanakan yang dipelajari oleh siswa (Taba, Hilda, 1962, Curriculum Development Theory and Practice.NewYork:Macmilllan Publishing Co,Inc). Sedangkan Beauchamp berpendapat bahwa kurikulum sebagai dokumen tertulis yang memuat rencana untuk peserta didik selama di sekolah (Beauchamp,George A.1975 Curriculum Theory, Wilmette. Illionois. The Kagg Press).

Sekolah sebagai lembaga pendidikan bagaimanapun juga memiliki pengaruh besar dalam pembentukan sistem sosial yang berkembang dalam suatu negara, kedudukannya sebagai pembentuk karakter dan paradigma masyarakat dimasa mendatang menjadi sesuatu yang strategis sehingga negara sangat berkepentingan untuk menguasai dan mengatur sekolah sebagai lembaga resmi yang berfungsi sebagai pendidikan rakyat. Perubahan kurikulum di indonesia dipengaruhi oleh perubahan politik yang terjadi disetiap masa, kurikulum 1997 yang dipimpin oleh Mr.Suwandi lebih menekankan kepada pendidikan kebangsaan dan rasa patriotisme (Departemen P\&K. 1985 Pendidikan Indonesia dari jaman ke jaman. Jakarata: Balai Pustaka h.148).

Secara global sasaran kurikulum yang menekankan rasa kebangsaan telah berhasil dilakukan, indikasi keberhasilan ini diperlihatkan pada paradigma politik saat ini dimana mayoritas masyarakat menginginkan bentuk negara kesatuan dan mempu meredam pemikiranpemikiran untuk memecah negara. Tetapi sasaran yang menekankan peningkatan sumber daya mengalami kegagalan hal ini diindikasikan lemahnya kemeampuan masyarakat dalam mengolah kekayaan alam. Indikasi lainnya berdarkan survei lembaga independen dunia yang memperlihatkan rendahnya pertumbuhan sumber daya manusia. 


\section{Peringkat Pembangunan SDM INDONESIA \\ Hasil survei UNDP \\ ( United Nation Development Program )}

\begin{tabular}{|c|c|}
\hline TAHUN & PERINGKAT \\
\hline 1995 & 104 \\
\hline 1996 & 102 \\
\hline 1997 & 99 \\
\hline 1998 & 105 \\
\hline 1999 & 109 \\
\hline 2001 & 102 \\
\hline 2002 & 110 \\
\hline 2004 & 111 \\
\hline 2005 & 110 \\
\hline
\end{tabular}

Berdasarkan kondisi tersebut Pemerintah melakukan perubahan kurikulum, berdasarkan tinjauan teoritis para ahli tentang penyebab rendahnya sumber daya manusia diantaranya adalah sistem pendidikan disekolah yang telalu menekankan ranah kognitif sehingga para peserta didik hanya menghapal konsep tatapi tidak memiliki kompetensi untuk menerapkan pengetahuannya, beban belajar terlalu berat dan lain-lain.

Sebagai tindak lanjut dari permasalahan tersebut tahun 2004 pemerintah memperkenalkan kurikulum berbasi kompetensi (KBK) dengan tanpa menghapus kurikulum 1994 yang berisifat Objective Based Curriculum, Kemudian tahun 2006 melalui Permen No.22 Tahun 2006 pemerintah menetapkan Kurikulum Tingkat Satuan Pendidikan (KTSP). Perbedaan mendasar KTSP dengan kurikulum sebelumnya adalah sekolah diberikan ruang untuk menyusun kurikulum sesuai dengan garis ketentuan oleh pemerintah.

Selama puluhan tahun bahkan sebelum indonesia merdeka model kurikulum selalu disusun oleh pemerintah, sekolah hanya menjalankan kurikulum tersebut tanpa menambah atau mengurangi kurikulum yang ditetapkan oleh pemerintah, dengan diberlakukan KTSP maka sekolah justru dituntut dan wajib menyusun kurikulum disesuaikan dengan potensi daerah masing-masing.

Perubahan ini menuntut sekolah untuk berkreasi dan melakukan inovasi, seberapa cepat Sekolah dapat beradapitasi dengan perubahan ini, sejauh mana kurikulum yang disusun oleh sekolah dapat mendongkrak mutu pendidikan indonesia.

Perubahan ini menjadi hal yang menarik untuk diteliti dalam perspektif evaluasi pelaksanaan KTSP di sekolah yang diharapkan dapat menjawab pertannyaan sejauh mana sekolah dapat 
menjalankan KTSP, sejauh mana KTSP diprediksi dapat meningkatkan mutu pendidikan, apakah kendala-kendala pelaksanaan KTSP dan perbaikan yang harus dilakuakan agar pelakasanaan KTSP dan mutu pendidikan dapat meningkat serta masalah-masalah lain yang menarik untuk diketahui para stakeholder

\section{Identifikasi Masalah}

Berdasarkan Latar Belakang Masalah di atas maka Identifikasi Masalah dalam penulisan ini adalah :

\section{Dalam sudut pandang konteks:}

Landasan formal kurikulum yang disusun atau digunakan sekolah.

\section{Dalam sudut pandang input:}

1. Sosialisasi terhadap pejabat sekolah, guru dan siswa, persiapan prasarana, ketersediaan informasi dan bahan-bahan ajar dan pembiayaan pada tahapan masukan dalam pelaksanaan KTSP.

2. SDM guru dalam penyusunan silabus dan perangkat pendidikan lainnya dan kemapuan guru dalam melakukan proses kegiatan belajar berdasarkan KTSP.

\section{Dalam sudut pandang Proses:}

Kegiatan sekolah dalam proses pembelajaran implementasi KTSP telah dijalankan dalam kegiatan sekolah.

\section{Dalam sudut pandang produk:}

Prestasi belajar, Kepribadian siswa dan tujuan-tujuan penerapan KTSP telah tercapai.

\section{Perumusan Masalah}

Dengan melihat Identifikasi Masalah diatas maka yang menjadi perhatian dan rumusan masalah dalam penulisan ini adalah:

\section{Dalam sudut pandang konteks:}

Bagaimanakah landasan formal kurikulum yang disusun atau digunakan sekolah? 


\section{Dalam sudut pandang input:}

1. Bagaimana sosialisasi terhadap pejabat sekolah, guru dan siswa, persiapan prasarana, ketersediaan informasi dan bahan-bahan ajar dan pembiayaan pada tahapan masukan dalam pelaksanaan KTSP?

2. Bagaimanakah SDM guru dalam penyusunan silabus dan perangkat pendidikan lainnya dan kemapuan guru dalam melakukan proses kegiatan belajar berdasarkan KTSP?

\section{Dalam sudut pandang Proses:}

Sejauh manakah kegiatan sekolah dalam proses pembelajaran implementasi KTSP telah dijalankan dalam kegiatan sekolah?

\section{Dalam sudut pandang produk:}

Sejauh manakah prestasi belajar, Kepribadian siswa dan tujuan-tujuan penerapan KTSP telah tercapai?

\section{Manfaat Evaluasi}

\section{Secara umum:}

1. Pengembangan bahan acuan untuk menyusun format evaluasi dalam pelaksanaan kurikulum disekolah-sekolah.

2. Memberikan sumbangsih pengembangan ilmu pengetahuan khususnya ilmu pendidikan mengenai evaluasi

\section{Bagi stakeholders tempat dilaksanakan evaluasi :}

Menemukan masalah-masalah real di lapangan untuk selanjutnya dapat dijadikan bahan informasi bagi pihak-pihak pengambil keputusan dalam menyusun dan pelaksanaan KTSP disekolah antara lain:

1. Kepala sekolah

2. Wakil Kepala sekolah

3. Tenaga pengajar 
4. Para peneliti dan pemerhati pendidikan dan pihak-pihak lainnya yang terkait dalam usaha peningkatan pendidikan.

\section{Metode Evaluasi}

\section{Jenis Pendekatan Evaluasi yang digunakan}

Terdapat enam pendekatan yang dapat digunakan dalam suatu evaluasi (Worthern, Blaine R and James R Sanders, 1987, Educational Evaluation : Alternative Approaches and practical Guidelines, NewYork: Longman Inc.) yaitu :

(1) Pendekatan orientasi objektif (objective oriented approach), (2)Pendekatan orientasi manajemen (Contex Input Process Product Model ), (3)Pendekatan orientasi konsumen (consumer oriented approaches), (4) Pendekatan orientasi pakar (Expertice Oriented Approaches), (5)Pendekatan Orentasi oposisi (Adversary oriented approaches), (6)Pendekatan orientasi stakeholder (naturalistic and participant oriented approaches).

Dari enam pendekatan evaluasi tersebut dalam evaluasi yang digunakan oleh peneliti adalah pendekatan evaluasi orientasi manajemen atau Contex Input Process Product Model (CIPP), CIPP dikembangkan oleh stufflebeam yang berpandangan evaluasi adalah proses untuk menggambarkan, memperoleh dan menyiapkan informasi berguna sebagai acuan untuk menilai suatu program yang dijalankan yang selanjutnya dapat membantu administrator membuat keputusan-keputusan yang tepat sebagai pengembangan atau perbaikan suatu program. 


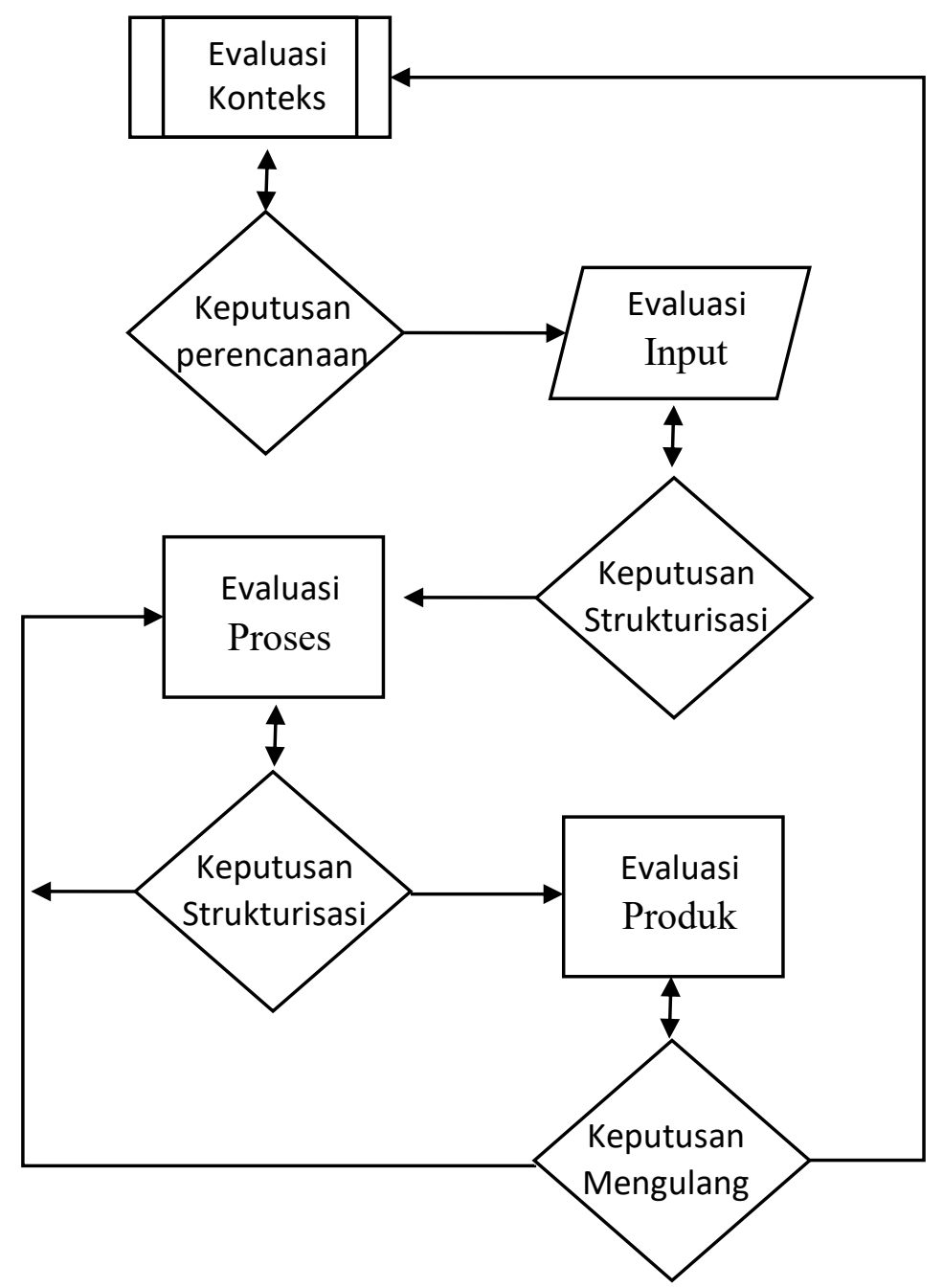

Gambar Hubungan Komponen CIPP

\section{Tujuan Kegiatan Evaluasi}

\section{Tujuan evalauasi dimaksudkan untuk:}

1. Menggambarkan landasan formal, analisis kebutuhan dan studi keberhasilan implementasi program KTSP disekolah tempat dilakukannya evaluasi (Contex)

2. Mengatahui tingkat efektifitas program KTSP yang berhubungan dengan kebijakan kepala sekolah, kordinasi para Wakil kepala sekolah. Sosok guru , informasi dan pelatihan, sarana/prasarana, pembiayaan dan siswa pada tahapan masukan (input).

3. Mengetahui tingkat efektifitas program KTSP yang berhubungna dengan persyaratan pelaksenaan proses pembelajaran dan proses pelaksanaan pembelajaran pada tahapan proses (Process) 
4. Mengetahui efektifitas keluaran pada prestasi belajar, keprbadian siswa pada tahapan $\operatorname{produk}(\operatorname{product})$.

\section{Tempat dan Waktu Evaluasi}

Tempat Evaluasi : SMP Negeri 37 Jakarta Selatan

Waktu evaluasi : Januari 2008- Aplul 2008

\section{Pertanyaan evaluasi}

Setelah melakukan evaluasi maka diharapkan dapat menjawab pertanyaan-pertanyaan sebagai berikut:

\section{Berkaitan dengan Konteks}

1. Apakah Kurikulum (KTSP) yang disusun telah sesuai dengan landasan dan petunjuk yang telah ditetapkan?

\section{Berkaitan dengan Input}

1. Apakah kebijakan dan keputusan pejabat sekolah berkenaan dengan persiapan KTSP telah memadai dalam mendukung terlaksananya KTSP?

2. Apakah kompetensi guru telah memadai dalam mendukung terlaksananya KTSP?

3. Apakah Informasi, prasarana dan biaya telah memadai dalam mendukung terlaksananya KTSP?

\section{Berkaitan dengan Proses}

1. Apakah persyaratan Pelaksanaan proses pembelajaran telah sesuai dengan standar proses?

2. Apakah apakah pelaksanaan pembelajaran telah sesuai dengan standar proses?

\section{Berkaitan dengan Produk}

1. Seberapa besar Prestasi belajar siswa setelah proses pembelajaran?

2. Bagaimanakan kepribadian siswa setelah proses pembelajaran? (Pertanyaan-pertanyaan tersebut telah melalui wawacara dengan para stakeholder)

\section{Metode Pengumpulan Data}

Model Evaluasi yang digunakan adalah model (contex input process product). Keputusan menggunakan model CIPP karena model evaluasi ini memberikan suatu kajian yang 
komprhensif dari kejadian sosial yang menjadi fokus perhatian dengan berorientasi pada pengambilan keputusan, Desain Evaluasi terlihat pada gambar berikut:

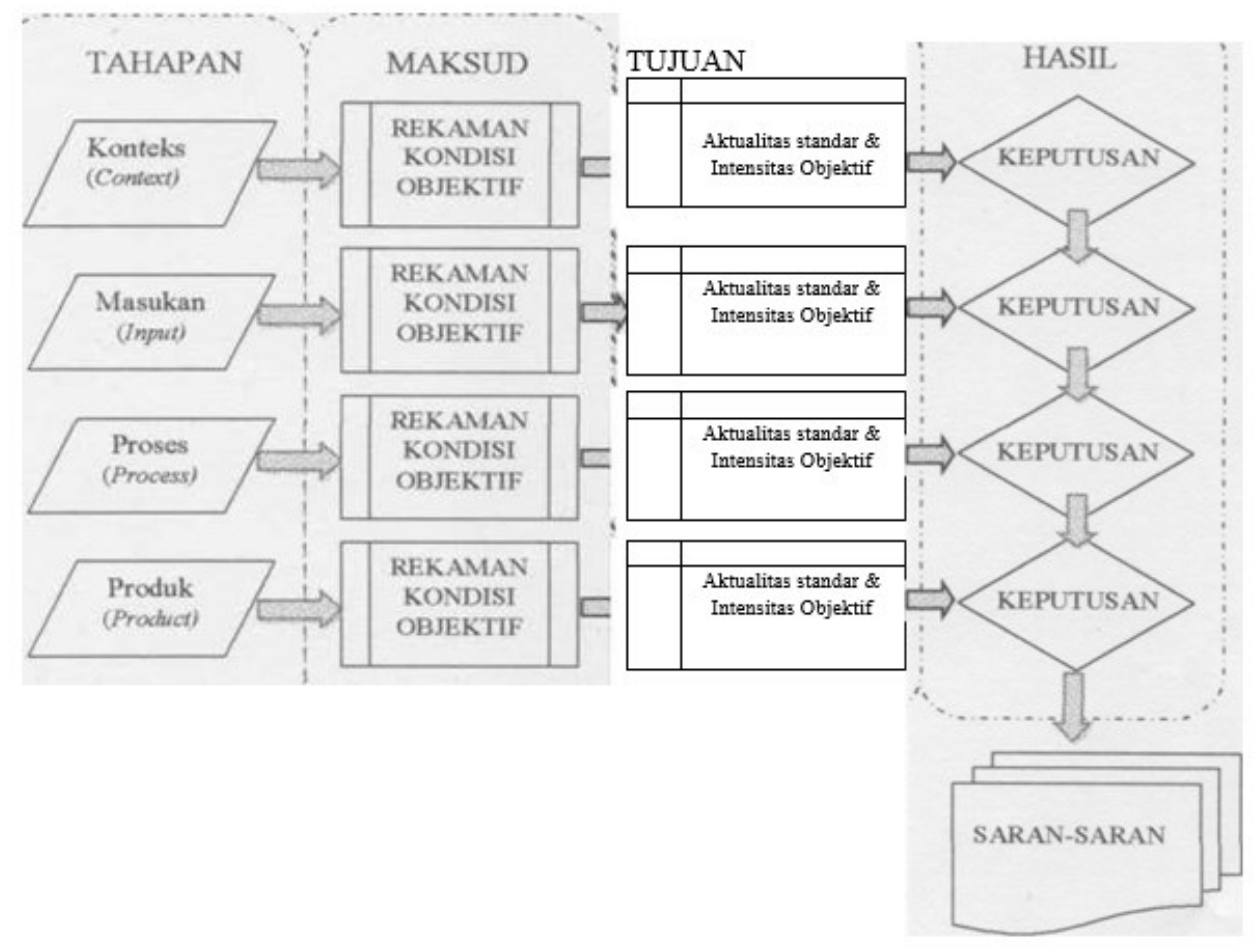

Gambar Desain Evaluasi

\section{Instrumen Pengumpulan Data}

Berdasarkan metode pengumpulan data dan standar objektif yang telah ditetapkan maka disusun instrumen pengumpulan data sebagai berikut:

\section{Instrumen-instrumen yang berkaitan pada tahap Konteks}

1. Instrumen Analisis Tujuan, Visi dan Misi program

Definisi konsep : Menganalisis sejauh mana kesesuaian antara Tujuan, Visi dan Misi sekolah yang telah disusun dengan standar objektif hasil pengkajian secara teoritis.

2. Instrumen Angket dengan masyarakat pendidikan, wali siswa, guru dan siswa mengenai arah dan materi pendidikan yang dibutuhkan oleh masyarakat.

Definisi konsep : Pendapat wali siswa dan guru mengenai kesesuaian tujuan, visi dan misi pendidikan sekolah dengan kebutuhan masyarakat lingkungan sekolah/daerah. 


\section{Kisi-kisi Angket kesesuaian tujuan, visi dan misi pendidikan sekolah}

\begin{tabular}{|c|l|c|}
\hline $\begin{array}{c}\text { Iinokun } \\
\text { Pertanyaan }\end{array}$ & Plihan jawaban & Pendapat \\
\hline $\begin{array}{c}\text { 1. Tujuan } \\
\text { pendidikan } \\
\text { sekolah }\end{array}$ & - Sesuai & Wali siswa Guru \\
& - Ragu-ragu & \\
\hline $\begin{array}{l}\text { 2. Visi pendidikan } \\
\text { sekolah }\end{array}$ & - Sesuai & Wali siswa Guru \\
& - Ragu-ragu & \\
\hline $\begin{array}{l}\text { 3. Misi } \\
\text { Pendidikan } \\
\text { sekolah }\end{array}$ & - Tidak sesuai & \\
\hline
\end{tabular}

3. Instrumen Analisis dokumen Kurikulum yang Telah Disususun/digunakan Sekolah. Definisi konsep : Menganalisis sejauh mana kesesuaian antara isi Kurikulum yang telah disusun/digunakan sekolah dengan standar objektif hasil pengkajian secara teoritis.

Kisi-kisi Instrumen Analisis dokumen Kurikulum yang Telah Disususun/digunakan Sekolah

\begin{tabular}{|c|c|c|}
\hline konteks & Standar objektif & keputusan \\
\hline $\begin{array}{l}\text { 1. Tujuan, visi dan misi } \\
\text { sekolah }\end{array}$ & $\begin{array}{l}\text { - Kesesuaian dengan } \\
\text { Landasan formal } \\
\text { negara }\end{array}$ & $\begin{array}{l}\text { Sesuai } \\
\text { Cukup sesuai tidak } \\
\text { sesuai }\end{array}$ \\
\hline 2. Struktur kurikulum & $\begin{array}{l}\text { - Kesesuaian dengan } \\
\text { Landasan formal } \\
\text { negara }\end{array}$ & $\begin{array}{l}\text { Sesuai } \\
\text { Cukup sesuai tidak } \\
\text { sesuai }\end{array}$ \\
\hline 3. Kalender pendidikan & $\begin{array}{l}\text { - Kesesuaian dengan } \\
\text { Landasan formal } \\
\text { negara }\end{array}$ & $\begin{array}{l}\text { Sesuai } \\
\text { Cukup sesuai tidak } \\
\text { sesuai }\end{array}$ \\
\hline 4. Silabus & $\begin{array}{l}\text { - Kesesuaian dengan } \\
\text { Landasan formal } \\
\text { negara }\end{array}$ & $\begin{array}{l}\text { Sesuai } \\
\text { Cukup sesuai tidak } \\
\text { sesuai }\end{array}$ \\
\hline
\end{tabular}




\section{Pedoman wawancara dengan kepala sekolah :}

Tujuan : untuk mengungkapkan mengenai

1. strategi persiapan pelaksanaan program

2. keputusan yang diambil dalam persiapan dan pelaksanaan program.

\section{Pedoman wawancara dengan para Wakil Kepala Sekolah}

Tujuan : untuk mengungkapkan mengenai:

1. strategi persiapan pelaksanaan program yang ditugaskan kepala sekolah kepadanya

2. keputusan yang diambil dalam persiapan dan pelaksanaan program

\section{Instrumen Observasi Profil guru}

Tujuan: untuk menegetahui Pendidikan terakhir guru, Kesesuaian keahlian dan studi yang diajarkan, Kondisi sosial ekonomi. Kisi-kisi instrumen terlihar pada tebel berikut:

\begin{tabular}{|c|l|l|}
\hline \multicolumn{1}{|c|}{ Aspek } & \multicolumn{1}{|c|}{ indikator } & No Item \\
\hline 1. Ketersediaan & Memiliki dokumen yang & $1,3,57$, \\
2. Memahami & dibutuhkan dalam KTSP & 9,11 \\
Ketentuan dalam & - memahami struktur & $2,4,6$, \\
KTSP & - memahami kaidah & $8,10,12$, \\
& $\begin{array}{l}\text { penyusunan silabus } \\
\text { - memahami teknik }\end{array}$ & 13,15 \\
& penilaian & 14,16 \\
& - memahami aturan & \\
& kalender pendidikan & \\
\hline
\end{tabular}

\section{Instrumen Inventori Sarana dan prasarana yang tersedia}

Diambil dari Buku petunjuk Evaluasi Diri jenjang SMP yang dikeluarkan Dinas Pendidikan Pemerintah Provinsi Daerah Jakarta. 


\section{Instrumen angket pembiayaan pelaksanaan program}

Diambil dari Buku petunjuk Evaluasi Diri jenjang SMP yang dikeluarkan Dinas Pendidikan Pemerintah Provinsi Daerah Jakarta

\section{Instrumen Analisis Prestasi Belajar Siswa Sebelum Penerapan KTSP}

Kisi-kisi analisis Prestasi Belajar

\begin{tabular}{|c|c|c|c|}
\hline $\begin{array}{c}\text { Fokus } \\
\text { Analisis }\end{array}$ & $\begin{array}{c}\text { Sumber } \\
\text { data }\end{array}$ & $\begin{array}{c}\text { Statistik } \\
\text { deskriptif }\end{array}$ & Kategori \\
\hline $\begin{array}{c}\text { 1. Prestasi } \\
\text { akademik }\end{array}$ & - Raport & Rata-rata & oTinggi oCukup o Rendah \\
\hline $\begin{array}{c}\text { 2. Dimensi } \\
\text { kepribadian }\end{array}$ & - Raport & Rata-rata & oTinggi oCukup o Rendah \\
\hline
\end{tabular}

\section{Instrumen-instrumen yang berkaitan pada tahap Proses}

1. Instrumen Observasi Persyaratan Pelaksanaan Proses Pembelajaran.

Fokus Pengamatan:
a. Rombongan belajar,
b. beban kerja minimal Guru,
c. Buku teks Pelajaran
d. Pengelolaan kelas

2. Instrumen observasi Pelaksanaan Pembelajaran (12 kali amatan).

Fokus pengamatan :
a. Mengenai pengelolaan kelas,
b. Pelaksanaan Pembelajaran,
c. Kegiatan Penutup

3. Instrumen Analisis Buku Agenda Kelas.

Fokus analisis :
a. Melaksanakan pembelajaran,
b. kehadiran guru dan 

c. kehadiran siswa
d. membimbing dan melatih
e. Tugas tambahan

4. Instrumen-instrumen yang berkaitan pada tahap Produk.

Instrumen analisis Raport dan Ujian Nasional :

Kisi-kisi Analisis Raport dan Ujian Nasional

\begin{tabular}{|l|l|l|l|}
\hline \multicolumn{1}{|c|}{ Fokus Analisis } & Sumber data & $\begin{array}{c}\text { Statistik } \\
\text { deskriptif }\end{array}$ & Kategori \\
\hline $\begin{array}{l}\text { Prestasi } \\
\text { akademik }\end{array}$ & $\begin{array}{l}\text { - UN } \\
\text { - Raport }\end{array}$ & $\begin{array}{l}\text { Rata-rata } \\
\text { persentil }\end{array}$ & $\begin{array}{l}\text { oTinggi } \\
\text { o Cukup } \\
\text { o Rendah }\end{array}$ \\
\hline
\end{tabular}

5. Instrumen Observasi mengenai kepribadian siswa

Kisi-kisi Analisis Kepribadian Siswa

\begin{tabular}{|l|l|l|l|}
\hline Fokus Analisis & Sumber data & $\begin{array}{l}\text { Statistik } \\
\text { deskriptif }\end{array}$ & Kategori \\
\hline Dimensi Pribadi & - Raport & Rata-rata & o Tinggi \\
& - Informasi & persentil & o Cukup \\
& -walikelas & & o Rendah \\
\hline
\end{tabular}

6. Analisis data lulusan yang meneruskan ke jenjang lebih tinggi.

Kisi-kisi Analisis Lulusan ke Jenjang Lebih Tinggi

\begin{tabular}{|l|l|l|l|}
\hline \multicolumn{1}{|c|}{ Fokus Analisis } & Sumber data & $\begin{array}{c}\text { Statistik } \\
\text { deskriptif }\end{array}$ & \multicolumn{1}{c|}{ Kategori } \\
\hline $\begin{array}{l}\text { Keberhasilan } \\
\text { siswa } \\
\text { meneruskan ke jenjeng } \\
\text { yang lebih tinggi }\end{array}$ & $\begin{array}{c}\text { - Dokumen } \\
\text { sekolah }\end{array}$ & $\begin{array}{l}\text { Rata-rata } \\
\text { persentil }\end{array}$ & $\begin{array}{l}\text { oTinggi } \\
\text { o Cukup } \\
\text { o Rendah }\end{array}$ \\
\hline
\end{tabular}




\section{Data yang diperoleh dianalisis dengan beberapa cara yaitu:}

1. Analisis Deskriptif

Analisisis Deskriftif dilakukan dengan mengolah data menggunakan statistik deskriftif sehingga didapat rata-rata, simpangan baku, distribusi frekuensi, median, modus, persentil dan grafik, sehingga diketahui kelemahan kelebihan atau hal-hal lain yang perlu diperhatikan

2. Persentase

Data yang didapat dikelompokkan berdasarkan acuan kriteria tinggi sedang dan rendah kemudian setiap kelompok disajikan dalam persen sehingga dapat diketahui kategori tinggi, sedang atau rendah.

3. Kategorisasi

Analisis yang dilakukan dengan membandingkan dokumen- dokuman temuan dengan standar objektif berdasarkan kajian teori atau landasan formal, dari hasil pembandingan tersebut dapat diambil kesimpulan sesuai/baik, cukup sesuai/cukup atau tidak sesuai/kurang.

4. Kalkulasi

Analisis yang dilakukan dengan menghitung pengeluaran yang dibutuhkan dan menghitung kemampuan dana yang dimiliki sehingga didapat kesimpulan lebih, cukup atau kurang.

\section{PEMBAHASAN DAN HASIL}

\section{Deskripsi Tempat Pelaksanaan Evaluasi}

\section{Sejarah SMPN 37 Jakarta}

SMPN 37 Jakarta didirikan tahun 1970 dengan nama SMP 37 Filial, berlokasi dijalan bumi kebayoran baru jakarta selatan, pada tahun 1979 SMP Filial remdi beruban namanya menjadi SMPN 37 Jakarta.

\section{Organisasi SMP Negeri 37 Jakarta.}

pengelolaan sekolah dipimpin oleh Kepala sekolah dengan wakil tiap bidang sebagai pembantu kepala sekolah dalam melaksanakan tugas-tugasnya di sekolah, selain itu kepala sekolah memiliki koordinasi yang sejajar dengan Komite sekolah sebagai lembaga 
masyarakat yang dibentuk oleh wali peserta didik sebagai wujud berfungsinya peran serta masyarakat dalam dunia pendidikan khususnya di sekolah bersangkutan, yang dalam hal ini sekolah tersebut adalah SMP Negeri 37 Jakarta. Bagan Organisasi SMP Negeri 37 Jakarta selatan diperlihatkan pada gambar berikut:

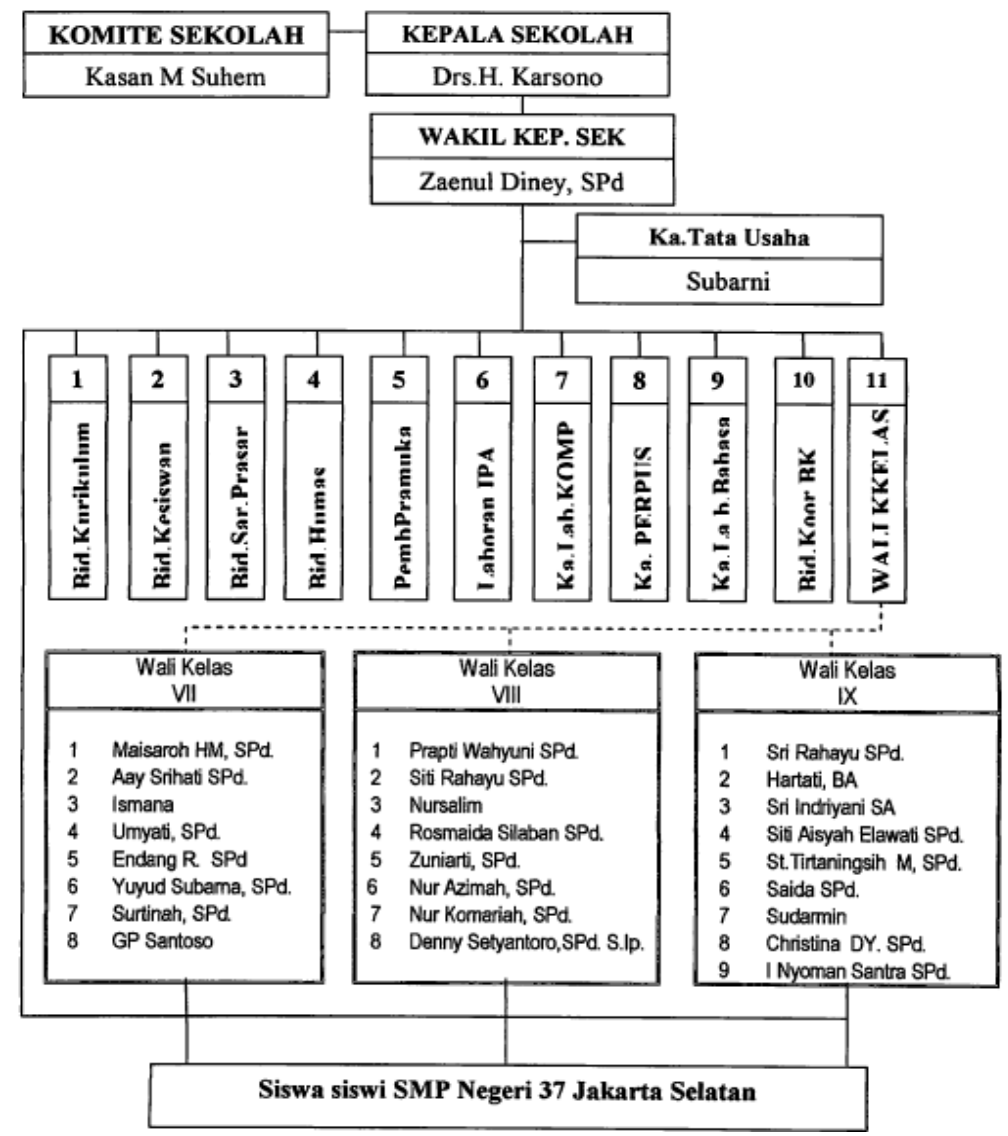

Struktur Organisasi SMPN 37 Jakarta

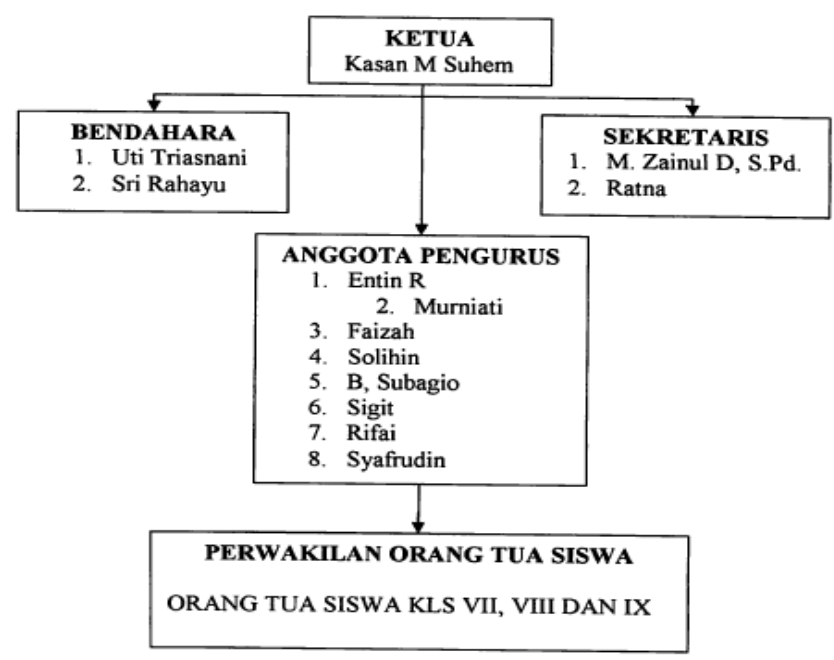

Struktur Komite Sekolah 


\section{Kondisi Objektif Program (Konteks)}

\section{Visi Misi dan Tujuan Pendidikan SMP Negeri 37 Jakarta}

Visi Sekolah Menengah Pertama Negeri 37 Jakarta :

\section{“UNGGUL DALAM MUTU, BERPRESTASI, BERBUDI PEKERTI LUHUR DAN BERAKHLAK MULIA, BERDASARKAN IMAN DAN TAQWA”.}

\section{Misi Sekolah Menengah Pertama Negeri 37 Jakarta :}

a. Melaksanakan pembelajaran dan bimbangan secara efektif sehingga setiap siswa berkembang secara optimal sesuai dengan potensi yang dimilikinya

b. Menumbuhkan semangat keunggulan secara intensif kepada seluruh warga sekolah

c. Menanamkan keyakinan terhadap kebesaran Tuhan Yang Maha Esa.

d. Meningkatkan kesadaran peserta didik sebagai makhluk sosial dalam tatanan kemasyarakatan, dan aktif memelihara/melestarikan lingkungan.

e. Mengembangkan pengetahuan dan keterampilan melalui pengalaman langsung sesuai dengan minat dan bakat peserta didik.

\section{Tujuan Sekolah Menengah Pertama Negeri 37 Jakarta:}

a. Meningkatkan perilaku akhlak mulia bagi peserta didik

b. Meningkatkan pengetahuan dan keterampilan yang sesuai dengan minat dan bakat peserta didik

Visi misi dan tujuan tersebut dianilisis secara konten dan telah sesuai dnegna Undang Republik Indonesia No 20 Tahun 2003 Tentang SistemPendidikan Nasional yang terkandung pada pasal 3 Yang berbunyi:

" Pendidikan nasional berfungsi mengembangkan kemampuan dan membentuk watak serta peradaban bangsa yang bermartabat dalam rangka mencerdaskan kehidupan bangsa, bertujuan untuk berkembangnya potensi peserta didik agar menjadi manusia yang beriman dan bertakwa kepada Tuhan Yang Maha Esa, berakhlak mulia, sehat, berilmu, cakap, kreatif, mandiri, dan menjadi warga negara yang demokratis serta bertanggung jawab". Visi SMP Negeri 37 tersebut juga telah melalui analisis kebutuhan masyarakat dengan melakukan penyebaran Angket kepada 50 responden yang dipilih secara acak yang merupakan bagian dari masyarakat pendidikan yaitu 40 reponden dari wali siswa dan 10 responden dari tenaga pengajar, Angket tersebut berisi pendapat masyarakat mengenai Kesesuaian Visi, Kejelasan Visi dan keterbutuhan masyarakta terhadap isi Visi tersebut. Hasil angket didapat sebagai berikut: 
Pendapat Masyarakat tentang Visi

\begin{tabular}{|c|c|c|c|}
\hline \multirow[t]{2}{*}{ Kesesuaian Visi } & SESUAI & $\begin{array}{l}\text { Row \% } \\
\text { Col \% }\end{array}$ & $\begin{array}{l}100.0 \% \\
100.0 \%\end{array}$ \\
\hline & Tidak SESUAI & $\begin{array}{l}\text { Row \% } \\
\text { Col \% }\end{array}$ & $\begin{array}{l}.0 \% \\
.0 \%\end{array}$ \\
\hline \multirow[t]{2}{*}{ Kejelasan Visi } & JELAS & $\begin{array}{l}\text { Row \% } \\
\text { Col \% }\end{array}$ & $\begin{array}{l}100.0 \% \\
100.0 \%\end{array}$ \\
\hline & Tidak JELAS & $\begin{array}{l}\text { Row \% } \\
\text { Col \% }\end{array}$ & $\begin{array}{l}.0 \% \\
.0 \%\end{array}$ \\
\hline \multirow[t]{2}{*}{ Visi Dibutuhkan } & DIBUTUHKAN & $\begin{array}{l}\text { Row \% } \\
\text { Col \% }\end{array}$ & $\begin{array}{l}100.0 \% \\
100.0 \%\end{array}$ \\
\hline & $\begin{array}{c}\text { Tidak } \\
\text { DIBUTUHKAN }\end{array}$ & $\begin{array}{l}\text { Row \% } \\
\text { Col \% }\end{array}$ & $\begin{array}{l}.0 \% \\
.0 \%\end{array}$ \\
\hline
\end{tabular}

Pendapat Masyarakat tentang Misi SMPN 37 Jakarta

\begin{tabular}{|c|c|c|c|}
\hline \multirow[t]{2}{*}{ Kesesuaian Misi } & SESUAI & $\begin{array}{l}\text { Row \% } \\
\text { Col \% }\end{array}$ & $\begin{array}{l}100.0 \% \\
100.0 \%\end{array}$ \\
\hline & Tidak SESUAI & $\begin{array}{l}\text { Row \% } \\
\text { Col \% }\end{array}$ & $\begin{array}{l}.0 \% \\
.0 \%\end{array}$ \\
\hline \multirow[t]{2}{*}{ Kejelasan Misi } & JELAS & $\begin{array}{l}\text { Row \% } \\
\text { Col \% }\end{array}$ & $\begin{array}{l}100.0 \% \\
100.0 \%\end{array}$ \\
\hline & Tidak JELAS & $\begin{array}{c}\text { Row \% } \\
\text { Col \% }\end{array}$ & $\begin{array}{l}.0 \% \\
.0 \%\end{array}$ \\
\hline \multirow[t]{2}{*}{ Misi Dibutuhkan } & DIBUTUHKAN & $\begin{array}{c}\text { Row \% } \\
\text { Col \% }\end{array}$ & $\begin{array}{l}100.0 \% \\
100.0 \%\end{array}$ \\
\hline & $\begin{array}{c}\text { Tidak } \\
\text { DIBUTUHKAN }\end{array}$ & $\begin{array}{l}\text { Row \% } \\
\text { Col \% }\end{array}$ & $\begin{array}{l}.0 \% \\
.0 \%\end{array}$ \\
\hline
\end{tabular}

Pendapat Masyarakat tentang Misi SMPN 37 Jakarta

\begin{tabular}{|c|c|c|c|}
\hline \multirow[t]{2}{*}{ Kesesuaian Misi } & SESUAI & $\begin{array}{l}\text { Row \% } \\
\text { Col \% }\end{array}$ & $\begin{array}{l}100.0 \% \\
100.0 \%\end{array}$ \\
\hline & Tidak SESUAI & $\begin{array}{l}\text { Row \% } \\
\text { Col \% }\end{array}$ & $\begin{array}{l}.0 \% \\
.0 \%\end{array}$ \\
\hline \multirow[t]{2}{*}{ Kejelasan Misi } & JELAS & $\begin{array}{c}\text { Row } \% \\
\text { Col } \%\end{array}$ & $\begin{array}{l}100.0 \% \\
100.0 \%\end{array}$ \\
\hline & Tidak JELAS & $\begin{array}{l}\text { Row \% } \\
\text { Col \% }\end{array}$ & $\begin{array}{l}.0 \% \\
.0 \%\end{array}$ \\
\hline \multirow[t]{2}{*}{ Misi Dibutuhkan } & DIBUTUHKAN & $\begin{array}{c}\text { Row \% } \\
\text { Col } \%\end{array}$ & $\begin{array}{l}100.0 \% \\
100.0 \%\end{array}$ \\
\hline & $\begin{array}{c}\text { Tidak } \\
\text { DIBUTUHKAN }\end{array}$ & $\begin{array}{l}\text { Row \% } \\
\text { Col \% }\end{array}$ & $\begin{array}{l}.0 \% \\
.0 \%\end{array}$ \\
\hline
\end{tabular}

Dari hasil angket tersebut mengindikasikan bahwa Tujuan yang disusun secara aktual benarbenar sesuai dengan ketentuan yang berlaku dan diterima oleh masyarakat. 


\section{Kurikulum SMP Negeri 37 Jakarta}

Struktur kurikulum disusun berdasarkan standar kompetensi lulusan dan standar kompetensi mata pelajaran dengan ketentuan sebagai berikut : (a) Kurikulum SMP Negeri 37 Jakarta memuat 10 mata pelajaran, muatan lokal, dan Pengembangan diri. Muatan lokal merupakan kegiatan kurikuler untuk mengembangkan kompetensi yang disesuaikan dengan cirri khas dan potensi daerah, termasuk keunggulan daerah, yang materinya tidak dapat dikelompokkan ke dalam mata pelajaran yang ada. Substansi muatan lokal ditentukan oleh satuan pendidikan. Pengembangan diri bukan merupakan mata pelajaran yang harus diasuh oleh guru. Pengembangan diri bertujuan memberikan kesempatan kepada peserta didik untuk mengembangkan dan mengekspresikan diri sesuai dengan kebutuhan, bakat, dan minat setiap peserta didik sesuai dengan kondisi sekolah. Kegiatan pengembangan diri difasilitasi dan atau dibimbing oleh konselor, guru, atau tenaga kependidikan yang dapat dilakukan dalam bentuk kegiatan ekstrakurikuler. Kegiatan pengembangan diri dilakukan melalui kegiatan pelayanan konseling yang berkenaan dengan masalah diri pribadi dan kehidupan social, belajar, dan pengembangan karir peserta didik.

\section{Struktur kurikulum}

a. Mata pelajaran

Berdasarkan hasil analisis struktur kurikulum berkaitan dengan mata pelajaran yang yang disusun oleh SMPN 37 Jakarta telah sesuai dengan landasan hukum diantaranya adalah :

1) PerMen Pendididikan Nasional No 24 Tentang Pelaksanaan Satandar Isi

2) Panduan Penyusunan KTSP dari BSNP

b. Muatan Lokal

Muatan lokal yang dikembangkan di SMPN 37 Jakarta adalah :

1) Tata Busana

2) PLKJ (Pendidikan Lingkungan Kehidupan Jakarta)

3) Praktik Bahasa Inggris.

Berdasarkan angket yang desebarkan ke 50 wali siswa SMPN 37

Jakarta didapat data sebagia berikut: 
Pendapat Masyarakat Tentang

Muatan Lokal yang dikembangkan di SMPN 37 Jakarta

\begin{tabular}{|ccc|c|}
\hline $\begin{array}{c}\text { Kesesuaian } \\
\text { dengan potensi } \\
\text { siswa }\end{array}$ & SESUAI & $\begin{array}{c}\text { Row } \% \\
\text { Col \% }\end{array}$ & $98.0 \%$ \\
& Tidak SESUAl & $\begin{array}{c}\text { Row } \% \\
\text { Col \% }\end{array}$ & $.2 \%$ \\
& & $.2 \%$ \\
Sesuai dgn & SESUAI & Row \% & $100.0 \%$ \\
potensi daerah & & Col \% & $100.0 \%$ \\
& Tidak SESUAI & Row $\%$ & $.0 \%$ \\
& & Col \% & $.0 \%$ \\
\hline
\end{tabular}

Berdasakan hasil analisis data dan angket tersebut maka dapat disimpulkan bahwa pelajaran muatan lokal yang dikembangkan pada SMPN 37 Jakarta telah sesui dengan landasan hukum, potensi siswa dan potensi daerah.

\section{Pengembangan Diri Siswa}

$\begin{array}{llll}\text { 1. } & \text { Pramuka } & \text { 6. } & \text { Bola Volley } \\ \text { 2. } & \text { PMR } & \text { 7. } & \text { Bola Basket } \\ \text { 3. } & \text { UKS } & \text { 8. } & \text { Tae Kwon Do } \\ \text { 4. } & \text { KIR } & \text { 9. } & \text { Pencak Silat } \\ \text { 5. } & \text { Rohis } & & \end{array}$

Pengembangan diri yang dikembangkan oleh SMPN 37 Jakarta seluruhnya berjumlah 13 kegiatan. Sehingga dapat disimpulkan bahwa pengembangan diri yang dikembangkan oleh SMPN 37 Jakarta telah sesuai dengan landasan hukum dan potensi siswa .

1. Pengaturan Beban Belajar

\section{Perhitungan Beban Belajar}

\begin{tabular}{|c|c|c|c|}
\hline $\begin{array}{c}\text { Satu jam } \\
\text { pemb.Tatap } \\
\text { muka(menit) }\end{array}$ & $\begin{array}{c}\text { Jumlah jam } \\
\text { pemb. } \\
\text { Per minggu }\end{array}$ & $\begin{array}{c}\text { Minggu efektif } \\
\text { per tahun } \\
\text { pelajaran }\end{array}$ & $\begin{array}{c}\text { Waktu } \\
\text { pembelajaran } \\
\text { per } \\
\text { tahun }\end{array}$ \\
\hline 40 & 36 & 34 & 1224 JP (48960) \\
\hline
\end{tabular}

Pengaturan beban belajar yang ditetapkan oleh SMPN 37 Jakarta tersebut telah sesuai dengan Peraturan Menteri Pendididikan Nasional No 22 Tentang Standar Isi dan Panduan Penyusunan KTSP dari BSNP, sehingga dapat disimpulkan bahwa Pangaturan beban belajar yang diterapkan di SMPN 37 Jakarta telah sesui dengan landasan hukum. 


\section{Ketuntasan Belajar.}

Ketuntasan belajar yang ditetapkan oleh SMPN 37 Jakarta tersebut telah sesuai dengan Peraturan Menteri Pendididikan Nasional No 22 Tentang Standar Isi dan Panduan Penyusunan KTSP dari BSNP, sehingga dapat disimpulkan bahwa Ketuntasan belajar yang diterapkan di SMPN 37 Jakarta telah sesui dengan landasan hukum

\section{Kenaikan Kelas dan Kelulusan}

\section{Kriteria Kenaikan Kelas}

a. Kenaikan kelas dilaksanakan pada setiap akhir tahun

b. Siswa dinyatakan naik kelas apabila yang bersangkutan telah mencapai kriteria ketuntasan minimal pada semua indikator. Kompetensi Dasar (KD), dan standar Kompetensi (SK) pada semua mata pelajaran

c. Siswa dinyatakan harus mengulang apabila belum mencapai kriteria ketuntasan minimal pada banyak indikator, KD, dan SK pada lebih dari empat (4) mata pelajaran sampai batas akhir tahun ajaran. Dan khusus untuk mata pelajaran matematika, IPA, Bahasa Indonesia dan bahasa Inggris minimal dua mata pelajaran tersebut tuntas.

d. Ketika mengulang di kelas yang sama, nilai siswa untuk semua indikator, KD, san SK yang ketuntasan belajar minimumnya sudah dicapai minimal sama dengan yang dicapai pada tahun sebelumnya.

Kriteria kenaikan kelas yang ditetapkan oleh SMPN 37 Jakarta tersebut telah sesuai dengan Peraturan Menteri Pendididikan Nasional No 22 Tentang Standar Isi dan Panduan Penyusunan KTSP dari BSNP, sehingga dapat disimpulkan bahwa Kriteria kenaikan kelas yang diterapkan di SMPN 37 Jakarta telah sesui dengan landasan hukum.

\section{Penunjang Pelaksanaan Program (Input)}

Penunjang pelaksaan program antara lain:

a. Kebijakan Kepala sekolah :

Berdasarkan hasil wawancara berkaitan dengan masalah:

1) Sumber informasi tentang KTSP

2) Analisis kendala yang dihadapi dalam penerapan KTSP

3) Langkah-langkah yang diambil dalam penerapan KTSP dan menangani masalah yang mungkin dihadapi

4) Keputusan Kongkrit yang diputuskan oleh kepala sekolah 
Dari hasil wawancara tersebut maka Kebijakan yang diambil oleh kepala sekolah dalam upaya pelaksanaan KTSP meliputi sosialisasi KTSP kepada staf, guru dan karyawan lingkup sekolah, menyusun KTSP dan perangkat yang dibutuhkan, melakukan alokasi dana untuk mendukung KTSP dan memfasilitasi sarana yang dibutuhkan dalam pelaksanaan KTSP seluruh lingkup tersebut dilakukan secara simultan, berdasarkan keadaan tersebut dapat disimpukan bahwa kebijakan yang diambil oleh kepala sekolah siam pelaksanaan KTSP telah maksimal dan tepat dalam mempertimbangkan kemampuan dan sumber-sumber yang dimiliki.

b. Koordinasi Para Wakil Kepala Sekolah

Dalam struktur organisasi SMP Negeri 37 Jakarta, Kepala sekolah sebagai Edukator, Manager, Administrator dan Supervisor, Pemimpin / Leader Inovator, Motivator (berdasarkan buku diskripsi tugas personil sekolah) memiliki wakil-wakil yang membantu dalam bidang tertentu diantaranya wakil kepala sekolah, wakil kepala bidang kurikulum, wakil kepala bidang Kesiswaan, wakil kepala bidang sarana prasarana, wakil kepala bidang humas.

Informasi yang didapat dari wawancara tentang:

1) Intruksi yang diterima dari Kepala sekolah berkaitan dengan persiapan pelaksanaan KTSP

2) Kordinasi antar waka berkaitan dengan kendala yang mungkin ditemui

3) Strategi/ langkah yang dilakukan oleh para waka dalam persiapan pelaksanaan KTSP dan menanggulangi masalah yang mungkin terjadi.

Dari hasil wawancara tersebut maka Kebijakan yang diambil oleh wakil kepala sekolah dalam upaya pelaksanaan KTSP dengan bersandar pada instruksi kepala sekolah dan memperhatikan dugaan kendala-kendala meliputi memberikan motivasi, mendatangkan narasumber dari luar memaksimalkan sarana yang dimiliki melakukan kordinasi secara aktif kepada guru-guru. Berdasarkan keadaan tersebut dapat disimpukan bahwa kebijakan yang diambil oleh wakil kepala sekolah dalam pelaksanaan KTSP telah maksimal dan tepat dalam mempertimbangkan kemampuan dan sumber-sumber yang dimiliki.

c. Profil tenaga pengajar

Profil tenaga pengajar yang diamati adalah:

1) Kualifikasi pendidikan guru. 
Statistik Deskriftif Kualifikasi Pendidikan Guru SM PN 37 Jakarta

\begin{tabular}{|c|c|c|c|}
\hline No & Kualifikasi pendidikan & Count & $\%$ \\
\hline 1 & S1 & 35 & 70 \\
\hline 2 & SarMud & 2 & 4 \\
\hline 3 & D3 & 6 & 12 \\
\hline 4 & D2 & 0 & 8 \\
\hline 5 & D1 & 3 & 6 \\
\hline 6 & SMA & 50 & 100 \\
\hline
\end{tabular}

2) Mengajar Sesuai dengan latar belakang pendidikan.

\begin{tabular}{|c|c|c|c|c|c|c|}
\hline & & $\begin{array}{c}\text { vn } \\
\text { (8kls) }\end{array}$ & $\begin{array}{c}\text { VIII } \\
(8 \mathrm{kls}) \\
\end{array}$ & $\begin{array}{c}\text { IX } \\
(9 \mathrm{kls})\end{array}$ & JML & $\begin{array}{c}\text { Jml Guru } \\
\text { minimum }\end{array}$ \\
\hline 1 & $\begin{array}{l}\text { Pendidikan agama: } \\
\text { a. Islam } \\
\text { b. Kristen/Katho }\end{array}$ & $\begin{array}{c}16 \\
4\end{array}$ & $\begin{array}{c}16 \\
4\end{array}$ & $\begin{array}{c}18 \\
4\end{array}$ & $\begin{array}{l}50 \\
12\end{array}$ & $\begin{array}{l}2 \\
1\end{array}$ \\
\hline 2 & PKn & 16 & 16 & 18 & 50 & 2 \\
\hline 3 & Bhs. Indonesia & 32 & 32 & 36 & 100 & 4 \\
\hline 4 & Matematika & 32 & 32 & 36 & 100 & 4 \\
\hline 5 & IPA / Sains: & 32 & 32 & 36 & 100 & 4 \\
\hline 6 & IPS & 32 & 32 & 36 & 100 & 4 \\
\hline 7 & Kertakes & 16 & 16 & 18 & 50 & 2 \\
\hline 8 & Penjaskes & 16 & 16 & 18 & 50 & 2 \\
\hline 9 & Bahasa Inggris & 32 & 32 & 36 & 100 & 4 \\
\hline 10 & $\begin{array}{l}\text { Muatan lokal: a. } \\
\text { PLKJ } \\
\text { b. Tata Busana }\end{array}$ & $\begin{array}{c}8 \\
16\end{array}$ & 16 & 9 & $\begin{array}{l}25 \\
50\end{array}$ & $\begin{array}{l}1 \\
2\end{array}$ \\
\hline 11 & Komputer / TI & 16 & 16 & 18 & 50 & 2 \\
\hline 12 & $\mathrm{BP} / \mathrm{BK}$ & 8 & 8 & 9 & 25 & 1 \\
\hline \multicolumn{6}{|c|}{ Jumlah guru yang dibutuhkan paling sedikit } & 35 \\
\hline
\end{tabular}


3) Kondisi sosial ekonomi menunjang

\begin{tabular}{|c|c|}
\hline \multicolumn{1}{|c|}{ Pendapatan } & Prosentasi \\
\hline Lebih kecil dari Rp 1.500.000 & $0 \%$ \\
\hline Antara Rp 1.500.000 hingga Rp 2.000.000 & $48 \%$ \\
\hline Antara Rp 2.000.000 hingga Rp 2.500.000 & $52 \%$ \\
\hline
\end{tabular}

4) Pemahaman Guru Terhadap KTSP

\begin{tabular}{|l|c|c|c|}
\cline { 3 - 4 } \multicolumn{1}{c|}{} & \multicolumn{3}{c|}{$\%$ Menjawab } \\
\hline Pertanyaan & Benar & Salah & $\begin{array}{c}\text { tdk } \\
\text { tahu }\end{array}$ \\
\hline $\begin{array}{l}\text { 1. Urutan berdasarkan hierarki konsep } \\
\text { disiplin ilmu dan/atau tingkat kesulitan } \\
\text { materi, harus selalu sesuai dengan urutan } \\
\text { yang ada di Standar ISI }\end{array}$ & $\mathbf{5 7 . 5 8}$ & $\mathbf{3 6 . 3 6}$ & $\mathbf{6 . 0 6}$ \\
\hline $\begin{array}{l}\text { 2. Guru boleh menoaanti materi pada buku } \\
\text { pelajaran jika terdapat materi lain yang lebih } \\
\text { berkaitan dengan masalah daerah yang } \\
\text { aktual. }\end{array}$ & $\mathbf{9 6 . 9 7}$ & $\mathbf{3 . 0 3}$ & - \\
\hline $\begin{array}{l}\text { 3. Pelaiaran muatan lokal diputuskan } \\
\text { berdasarkan potensi peserta didik. }\end{array}$ & $\mathbf{2 4 . 2 4}$ & $\mathbf{7 5 . 7 6}$ & - \\
$\begin{array}{l}\text { Sedangkan isi pengembangan diri } \\
\text { diputuskan berdasarkan potensi daerah . }\end{array}$ & & & \\
\hline $\begin{array}{l}\text { 4. Penilaian yang diterapkan adalah penilaian } \\
\text { dengan acuan kriteria (bukan acuan } \\
\text { kelompok). }\end{array}$ & $\mathbf{1 0 0 . 0 0}$ & - & - \\
\hline $\begin{array}{l}\text { 5. Sekolah tidak dapat memutuskan seorang } \\
\text { siswa tidak lulus jika siswa tersebut lulus }\end{array}$ & $\mathbf{4 5 . 4 5}$ & $\mathbf{5 1 . 5 2}$ & $\mathbf{3 . 0 3}$ \\
\hline $\begin{array}{l}\text { Ujian Nasional } \\
\text { 6. Alokasi waktu setiap 1 jam pelajaran tidak } \\
\text { boleh kurang atau lebih dari 40 menit }\end{array}$ & $\mathbf{5 7 . 5 8}$ & $\mathbf{4 2 . 4 2}$ & - \\
\hline
\end{tabular}


Ketersediaan Informasi Tentang KTSP

Memiliki Dokumen yang dibutuhkan dalam pelaksanaan KTSP

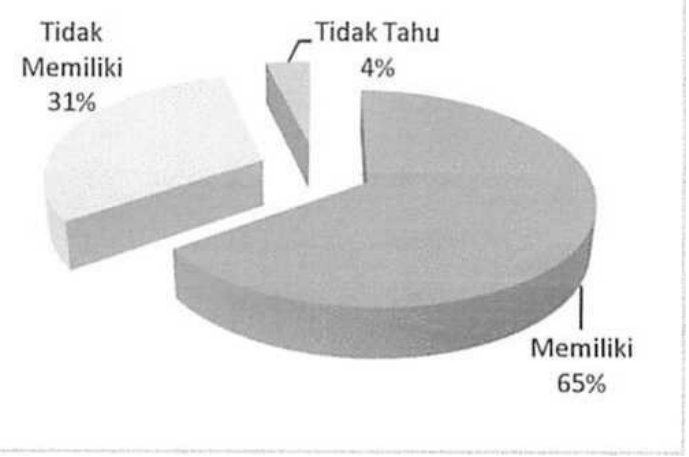

\begin{tabular}{|c|c|c|c|c|c|}
\hline \multirow[b]{2}{*}{ Lingkup } & \multirow[b]{2}{*}{ Indikator } & \multirow[b]{2}{*}{ Item } & \multicolumn{3}{|c|}{ \% menjawab } \\
\hline & & & Benar & Salah & $\begin{array}{l}\text { tida } \\
\text { k } \\
\text { tahu }\end{array}$ \\
\hline \multirow{5}{*}{$\begin{array}{l}\text { Memahami } \\
\text { Ketentuan dalam } \\
\text { KTSP }\end{array}$} & $\begin{array}{l}\text { - memahami struktur } \\
\text { Kurikulum }\end{array}$ & $2,4,6$ & 65.66 & 29.29 & 3.03 \\
\hline & $\begin{array}{l}\text { - memahami kaidah } \\
\text { penyusunan silabus }\end{array}$ & $8,10,12$, & 86.87 & 9.09 & 4.04 \\
\hline & $\begin{array}{l}\text { - mamahami teknik } \\
\text { penilaian }\end{array}$ & 13,15 & 34.85 & 63.64 & 1.52 \\
\hline & $\begin{array}{l}\text { - memahami aturan } \\
\text { kalender pendidikan }\end{array}$ & 14,16 & 78.79 & 21.21 & - \\
\hline & & total & 66.54 & 30.81 & 2.15 \\
\hline
\end{tabular}

Berdasarkan data tersebut diketahui bahwa 70\% guru teah berkualifikasi Sarjana dan $30 \%$ guru belum memiliki kualifikasi sarjana, 76\% mengajar sesuai dengan latar belakang pendidikan, 100\% guru memiliki pendapatan diatas 1,5 juta per bulan, guru yang memiliki ketersediaan informasi sebesar $65 \%$ dan dan guru yang memahami aturan KTSP sebesar $66,54 \%$ berdasarkan data tersebut maka profil guru disimpulkan cukup mendukung terlaksanya KTSP .

\section{Sarana Prasarana}

Berdasarkan data-data yang dikumpulkan tersebut maka ketersediaan sarana dan prasarana cukup untuk mendukung terlaksananya KTSP

\section{Pembiayaan Pelaksaan Program}


Untuk mendukung terlaksananya Program maka sisi pembiayaan merupakan bagian yang vital diperlukan sehingga perlu dilakukan penyusunan anggaran dalam mengalikasikan biaya yang realistis dalam setiap agenda kegiatan yang terkandung pada program. Alokasi anggaran belanja sekolah SMP Negeri 37 Jakarta adalah sebagai berikut:

\begin{tabular}{|c|c|c|}
\hline NO & KEGIATAN POKOK & TOTAL PEMBIAYAAN \\
\hline 1 & Pengelolaan Kurikulum & Rp36,024,000.00 \\
\hline 2 & $\begin{array}{l}\text { Pengelolaan Kegiatan Belajar } \\
\text { Mengajar }\end{array}$ & Rp149,190,000.00 \\
\hline 3 & Pelaksanaan Penilaian & Rp130,500,500.00 \\
\hline 4 & $\begin{array}{l}\text { Kegiatan Kesiswaan / } \\
\text { Ekstrakurikuler }\end{array}$ & Rp164,284,000.00 \\
\hline 5 & $\begin{array}{l}\text { Peningkatan Mutu Proses } \\
\text { Pembelajaran }\end{array}$ & Rp110,136,000.00 \\
\hline 6 & $\begin{array}{l}\text { Pemeliharan /Perawatan / } \\
\text { Peng.Sarana Prasarana }\end{array}$ & $\operatorname{Rp} 438,926,500.00$ \\
\hline 7 & $\begin{array}{l}\text { Pengembangan Sumber Daya } \\
\text { Manusia }\end{array}$ & $\operatorname{Rp} 220,920,000.00$ \\
\hline 8 & Pengelolaan Perkantoran & $\operatorname{Rp} 73,250,000.00$ \\
\hline 9 & Kesejahteraan Guru dan Pegawai & Rp 3,020,564,700.00 \\
\hline 10 & $\begin{array}{l}\text { Rumahtangga Sekolah Daya dan } \\
\text { Jasa }\end{array}$ & Rp $101,280,000.00$ \\
\hline 11 & $\begin{array}{l}\text { Pengembangan Manajemen } \\
\text { Sekolah }\end{array}$ & Rp 54,029,000.00 \\
\hline 12 & Hubungan Masyarakat & $\mathrm{Rp} 38,398,000.00$ \\
\hline 13 & Supervisi & Rp 5,900,000.00 \\
\hline 14 & Monitoring Dan Evaluasi & Rp 3,900,000.00 \\
\hline & Jumlah Seluruhnya & $\operatorname{Rp} 4,547,302,700.00$ \\
\hline
\end{tabular}

Sumber pembiayaan pendanaan anggaran belanja Sekolah SMP Negeri 37 Jakarta tahun 2007-2008

\begin{tabular}{|l|l|r|}
\hline No. & \multicolumn{1}{|c|}{ Sumber } & \multicolumn{1}{c|}{ Jumlah $(\mathrm{Rp})$} \\
\hline 1 & APBD Kab/Kota & Rp. 4,090,964,700.00 \\
\hline 2 & Orang Tua Siswa & Rp. 456,338,000.00 \\
\hline 3 & APBN & - \\
\hline 4 & Sumber Lain & Rp. 4,547,302,700.00 \\
\hline & TOTAL &
\end{tabular}


Berdasarkan data-data tersebut maka dapat ditarik kesimpulan bahwa pendanaan cukup tersedia dalam mendukung terlaksananya KTSP.

\section{Informasi objektif peserta didik}
a. Gambaran umum siswa SMP Negeri 37 Jakarta
b. Rata-rata prestasi akademik sebelum KTSP.
c. Dimensi kreatifitas sebelum KTSP
d. Dimensi Kepribadian sebelum KTSP

\section{Impementasi Penyelenggaraan Program (Proses)}

\section{Rombongan Belajar}

Rombongan belajar berdasarkan Standar Proses untuk tingkat SMP maksimum 32 siswa,

\section{Rekap Rombongan Belajar (2007/2008)}

\begin{tabular}{|c|c|c|c|c|c|}
\hline No & Kelas & $\begin{array}{c}\text { Siswa } \\
\text { Pria }\end{array}$ & $\begin{array}{c}\text { Siswa } \\
\text { wanita }\end{array}$ & Jumlah & Kriteria \\
\hline 1 & VII.1 & $\mathbf{2 0}$ & $\mathbf{2 0}$ & $\mathbf{4 0}$ & Tidak Sesuai \\
\hline 2 & VII.2 & $\mathbf{2 0}$ & $\mathbf{2 0}$ & $\mathbf{4 0}$ & Tidak Sesuai \\
\hline 3 & VII.3 & $\mathbf{2 0}$ & $\mathbf{2 0}$ & $\mathbf{4 0}$ & Tidak Sesuai \\
\hline 4 & VII.4 & $\mathbf{1 9}$ & $\mathbf{2 1}$ & $\mathbf{4 0}$ & Tidak Sesuai \\
\hline 5 & VII.5 & $\mathbf{2 0}$ & $\mathbf{2 0}$ & $\mathbf{4 0}$ & Tidak Sesuai \\
\hline 6 & VII.6 & $\mathbf{2 0}$ & $\mathbf{2 0}$ & $\mathbf{4 0}$ & Tidak Sesuai \\
\hline 7 & VII.7 & $\mathbf{2 0}$ & $\mathbf{2 0}$ & $\mathbf{4 0}$ & Tidak Sesuai \\
\hline 8 & VII.8 & $\mathbf{1 9}$ & $\mathbf{2 1}$ & $\mathbf{4 0}$ & Tidak Sesuai \\
\hline 9 & VII.9 & $\mathbf{2 0}$ & $\mathbf{2 0}$ & $\mathbf{4 0}$ & Tidak Sesuai \\
\hline 10 & VIII.1 & $\mathbf{2 0}$ & $\mathbf{2 2}$ & $\mathbf{4 2}$ & Tidak Sesuai \\
\hline 11 & VIII.2 & $\mathbf{2 0}$ & $\mathbf{2 2}$ & $\mathbf{4 2}$ & Tidak Sesuai \\
\hline 12 & VIII.3 & $\mathbf{2 0}$ & $\mathbf{2 2}$ & $\mathbf{4 2}$ & Tidak Sesuai \\
\hline 13 & VIII.4 & $\mathbf{2 0}$ & $\mathbf{2 2}$ & $\mathbf{4 2}$ & Tidak Sesuai \\
\hline 14 & VIII.5 & $\mathbf{2 0}$ & $\mathbf{2 2}$ & $\mathbf{4 2}$ & Tidak Sesuai \\
\hline 15 & VIII.6 & $\mathbf{1 9}$ & $\mathbf{2 2}$ & $\mathbf{4 1}$ & Tidak Sesuai \\
\hline 16 & VIII.7 & $\mathbf{1 8}$ & $\mathbf{2 4}$ & $\mathbf{4 2}$ & Tidak Sesuai \\
\hline 17 & VIII.8 & $\mathbf{1 8}$ & $\mathbf{2 4}$ & $\mathbf{4 2}$ & Tidak Sesuai \\
\hline 18 & VIII.9 & $\mathbf{1 8}$ & $\mathbf{2 4}$ & $\mathbf{4 2}$ & Tidak Sesuai \\
\hline 19 & IX.1 & $\mathbf{2 2}$ & $\mathbf{2 2}$ & $\mathbf{4 4}$ & Tidak Sesuai \\
\hline 20 & IX.2 & $\mathbf{2 2}$ & $\mathbf{2 2}$ & $\mathbf{4 4}$ & Tidak Sesuai \\
\hline 21 & IX.3 & $\mathbf{2 2}$ & $\mathbf{2 0}$ & $\mathbf{4 2}$ & Tidak Sesuai \\
\hline 19 & IX.4 & $\mathbf{2 1}$ & $\mathbf{2 2}$ & $\mathbf{4 3}$ & Tidak Sesuai \\
\hline 23 & IX.5 & $\mathbf{2 0}$ & $\mathbf{2 2}$ & $\mathbf{4 2}$ & Tidak Sesuai \\
\hline 24 & IX.6 & $\mathbf{2 0}$ & $\mathbf{2 2}$ & $\mathbf{4 2}$ & Tidak Sesuai \\
\hline 25 & IX.7 & $\mathbf{2 0}$ & $\mathbf{2 2}$ & $\mathbf{4 2}$ & Tidak Sesuai \\
\hline 26 & IX.8 & $\mathbf{2 0}$ & $\mathbf{2 2}$ & $\mathbf{4 2}$ & Tidak Sesuai \\
\hline
\end{tabular}


Berdasarkan hasil observasi tersebut maka dapat diketahui bahwa proporsi jumlah rombongan belajar pada SMP Negeri 37 Jakarta 100\% tidak sesuai dengan Standar Proses belajar.

\section{Beban Kerja Minimal Guru}

\begin{tabular}{|c|c|c|c|}
\hline No & Indikator & keterangan & Kriteria \\
\hline 1 & $\begin{array}{c}\text { Merencanakan } \\
\text { Pembelajaran }\end{array}$ & $\begin{array}{c}100 \% \text { Guru } \\
\text { memiliki RPP* }\end{array}$ & Sesuai \\
\hline 2 & $\begin{array}{c}\text { Melaksanakan } \\
\text { Pembelajaran }\end{array}$ & $\begin{array}{c}95 \% \text { kehadiran } \\
\text { Guru dikelas** }\end{array}$ & Sesuai \\
\hline 3 & $\begin{array}{c}\text { Menilai hasil } \\
\text { Pembelajaran }\end{array}$ & $\begin{array}{c}100 \% \text { Guru } \\
\text { melakukan } \\
\text { penilaian })^{* * *}\end{array}$ & Sesuai \\
\hline 4 & $\begin{array}{c}\text { Membimbing dan } \\
\text { melatih }\end{array}$ & $\begin{array}{c}85 \% \text { Guru } \\
\text { membimbing dan } \\
\text { melatih**** }\end{array}$ & Sesuai \\
\hline 5 & Tugas tambahan & $\begin{array}{c}80 \% \text { Guru } \\
\text { memberikan tugas } \\
\text { tambahan**** }\end{array}$ & Sesuai \\
\hline 6 & Beban kerja guru & $\begin{array}{c}98 \% \text { beban kerja } \\
\text { guru lebih kecil dari } \\
24 \text { jam /minggu }\end{array}$ & Tidak Sesuai \\
\hline
\end{tabular}

\section{Hasil Studi Dokumen dam wawancara}

** Hasil Studi dokumen (agenda kelas selama 60 Hari belajar)

*** Hasil Wawancara

**** Hasil pengamatan dikelas selama 12 hari pelajaran Berdasarkan tabel tersebut dari 6 indikator terdapat 5 indikator yang sesuai dan 1 indikator yang sesuai.

\section{Metode belajar}

Berdasarkan hasil pengamatan sebanyak 50 kali amatan yang dilakukan selama 12 hari didapat bahwa kegaitan guru berkenaan dengan Metode belajar setelah melalui analisa menggunakan SPSS didapat tabel sebagai berikut:

Variasi Metode Belajar di SMPN 37 Jakarta

\begin{tabular}{|c|c|c|}
\hline & \multicolumn{2}{|c|}{ Metode Belajar } \\
\hline & Count & $\%$ \\
\hline Ceramah & 42 & $36.8 \%$ \\
Tanya Jawab & 8 & $7.0 \%$ \\
Praktik & 12 & $10.5 \%$ \\
Diskusi & 26 & $19.8 \%$ \\
Demonstrasi & 20 & $17.5 \%$ \\
Penugasan & 6 & $5.3 \%$ \\
\hline
\end{tabular}


Metode yang paling sering digunakan adalah ceramah sebanyak 36,8\%, praktik 10,5\% dan metode lainnya sebesar $52,7 \%$. Berdasarkan data tersebut maka dalam proses pelaksanaan KTSP metode belajar yang dilaksanakan guru dalam kategori baik (bervariasi).

\section{Pencapaian Program}

\section{Prestasi Belajar Siswa.}

Berdasarkan hasil rata-rata Ujian Nasional dalam sejak tahun 2001 sampai dengan 2007 adalah sebagai berikut:

\begin{tabular}{|c|c|c|}
\multicolumn{2}{|c|}{ Rata-rata Ujian Nasional SMPN 37 Jakarta } \\
\hline \multirow{2}{*}{$\begin{array}{c}\text { Tahun } \\
\text { Pelajaran }\end{array}$} & \multicolumn{2}{|c|}{ Rata - Rata } \\
\cline { 2 - 3 } & Hasil & Target \\
\hline $2001 / 2002$ & $\mathbf{5 , 7 6}$ & $\mathbf{6 , 0 0}$ \\
\hline $2002 / 2003$ & $\mathbf{6 , 8 3}$ & $\mathbf{6 , 0 0}$ \\
\hline $2003 / 2004$ & $\mathbf{6 , 4 0}$ & $\mathbf{6 , 0 0}$ \\
\hline $2005 / 2006$ & $\mathbf{6 , 8 7}$ & $\mathbf{6 . 0 0}$ \\
\hline $2006 / 2007$ & $\mathbf{6 , 8 1}$ & $\mathbf{6 , 0 0}$ \\
\hline
\end{tabular}

Tabel tersebut memperlihatkan bahwa Rata-rata UNAS tahun 2005/2006 (sebelum KTSP) lebih besar 0,06 dari tahun 2006/2007 (setelah KTSP), penurunan nilai UNAS/UN (Ujian Nasional) yang kecil tersebut tidak dapat membuktikan bahwa penerapan KTSP di SMPN 37 dalam meningkatkan prestasi belajar tidak berhasil hal ini didasari adanya kemungkinan kualitas input yang berbeda dan bobot soal UNAS yang berbeda, selain itu sebelum ketentuan KTSP ditetapkan konsentrasi kurikulum tidak memperhatikan potensi siswa dan potensi daerah sehingga fokus pembelajaran lebih kuat pada ranah kognitif. Sebaliknya KTSP mengamanatkan agar kurikulum yang disusun memperhatikan

potensi daerah dan potensi siswa serta penekanan pada kompetensi, keadaan ini menurunkan fokus pembelajaran pada ranah kognitif sehingga diduga dapat menurunkan hasil UNAS. 
Berdasarkan rapor 50 siswa yang dipilih secara acak didapat perhitungan statistik sebagai berikut:

Perhitungn statistik rapor 50 siswa

\begin{tabular}{|c|c|c|}
\hline & $\begin{array}{l}\text { Sebelum } \\
\text { KTSP }\end{array}$ & Setelah KTSP \\
\hline Mean & 8.12 & 68.27 \\
\hline Median & 67.98 & 68.46 \\
\hline Mode & 65.01785714 & 70.33004926 \\
\hline Std. Deviation & 3.740393099 & 2.88194714 \\
\hline Variance & 13.99054053 & 8.307348577 \\
\hline Range & & \\
\hline Minimum & 6.79 & 58.61 \\
\hline Maximum & 75.88 & 72.58 \\
\hline Sum & $2,316.07$ & $2,321.33$ \\
\hline
\end{tabular}

Tabel distribusi hasil belajar sebelum dan sesudah KTSP

\begin{tabular}{|c|c|c|c|c|c|c|c|c|c|c|}
\hline \multirow{4}{*}{$\frac{\text { No }}{1}$} & & & & \multirow{4}{*}{$\begin{array}{c}\begin{array}{c}\text { Nilai } \\
\text { Tengah }\end{array} \\
56.5\end{array}$} & \multirow{2}{*}{\multicolumn{3}{|c|}{$\begin{array}{c}\text { Sebelum KTSP } \\
\text { Frekwensi }\end{array}$}} & \multirow{2}{*}{\multicolumn{3}{|c|}{$\begin{array}{c}\text { Setelah KTSP } \\
\text { Frekwensi }\end{array}$}} \\
\hline & \multirow{2}{*}{\multicolumn{3}{|c|}{$\begin{array}{c}\text { Kelas } \\
\text { interval }\end{array}$}} & & & & & & & \\
\hline & & & & & \multirow{2}{*}{\begin{tabular}{|c|} 
Absolut \\
1
\end{tabular}} & \multirow{2}{*}{$\begin{array}{c}\text { Relatif } \\
(\%)\end{array}$} & \multirow{2}{*}{$\begin{array}{c}\text { Komulatif } \\
(\%)\end{array}$} & \multirow{2}{*}{$\frac{\text { Absolut }}{0}$} & \multirow{2}{*}{$\begin{array}{c}\begin{array}{c}\text { Relatif } \\
(\%)\end{array} \\
-\end{array}$} & \multirow{2}{*}{$\begin{array}{c}\text { Komulatif } \\
(\%)\end{array}$} \\
\hline & 55 & - & 58 & & & & & & & \\
\hline 2 & 59 & - & 62 & 60.5 & 0 & - & 2.94 & 1 & 2.94 & 2.94 \\
\hline 3 & 63 & - & 66 & 64.5 & 7 & 20.59 & 23.53 & 4 & 11.76 & 14.71 \\
\hline 4 & 67 & - & 70 & 68.5 & 15 & 44.12 & 67.65 & 18 & 52.94 & 67.65 \\
\hline 5 & 71 & - & 74 & 72.5 & 8 & 23.53 & 91.18 & 11 & 32.35 & 100.00 \\
\hline 6 & 75 & - & 78 & 76.5 & 3 & 8.82 & 100.00 & 0 & - & 100.00 \\
\hline 7 & 79 & - & 82 & 80.5 & 0 & - & 100.00 & 0 & - & 100.00 \\
\hline
\end{tabular}




\section{Diagran Prestasi Belajar Sebelum Dan Sesudah KTSP}

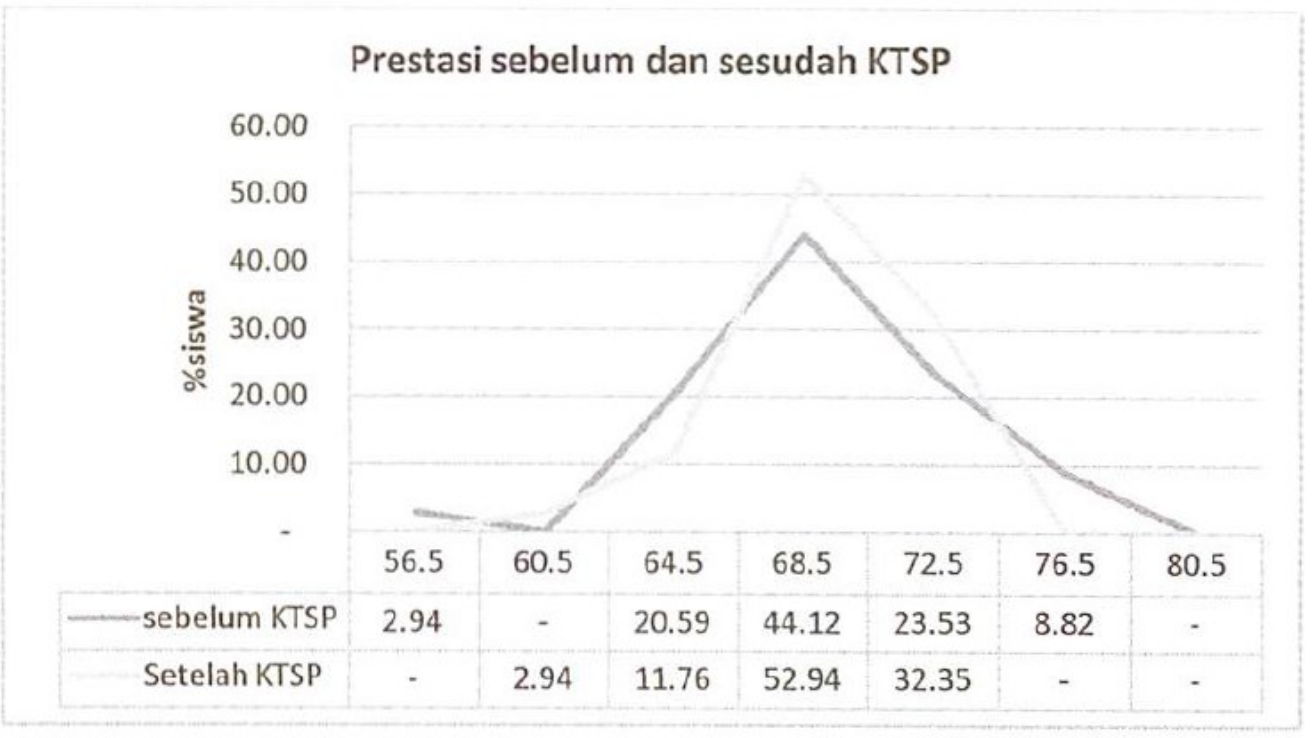

Berdasarkan perbedaan antara rata-rata, standar deviasi dan varian maka prestasi belajar setelah KTSP penyebaran prestasi belajar siswa berkurang artinya perbedaan nilai antar siswa semakin kecil. Jika lebih diam lagi dianalisis diketahui bahwa sebelum KTSP 76,47\% siswa memiliki nilai diatas 67 dan setelah KTSP 85,29\% siswa memiliki nilai diatas 67 hal ini membuktikan bahwa setalah dilaksanakannya KTSP terjadi peningkatan prestasi belajar.

\section{Kepribadian Siswa}

Berdasarkan analisis raport 50 siswa kelas 3 yang dipilih secara acak didapat data sebagai berikut:

Tabel Distribusi Frekwensi Perkembangan Nilai Kepribadian Dalam 5 semester

\begin{tabular}{|c|r|r|r|r|r|}
\cline { 2 - 6 } \multicolumn{1}{c|}{} & \multicolumn{2}{c|}{ Kelas 7 } & \multicolumn{3}{c|}{ Kelas 7 \& 8 } \\
\cline { 2 - 7 } \multicolumn{1}{c|}{} & smt1 & \multicolumn{1}{c|}{ smt2 } & smt3 & \multicolumn{1}{c|}{ smt4 } & smt5 \\
\hline sangat baik \% & 1.79 & 1.67 & 1.56 & 1.56 & 0 \\
\hline baik \% & 94.64 & 93.33 & 95.31 & 98.44 & 98.4375 \\
\hline cukup baik \% & 3.57 & 5.00 & 3.13 & & 1.5625 \\
\hline total & 100.00 & 100.00 & 100.00 & 100.00 & 100 \\
\hline
\end{tabular}


Tabel Distribusi Frekwensi Nilai Kepribadian

Sebelum dan Sesudah KTSP

\begin{tabular}{|c|c|c|}
\hline & $\begin{array}{c}\text { Sebelum } \\
\text { KTSP }\end{array}$ & $\begin{array}{c}\text { Setelah } \\
\text { KTSP }\end{array}$ \\
\hline sangat baik & 1.72 & 1.04 \\
\hline baik & 93.97 & 97.40 \\
\hline cukup baik & 4.31 & 1.56 \\
\hline & 100.00 & 100.00 \\
\hline
\end{tabular}

Bedasarkan hasil tersebut diketahui bahwa setelah KTSP terjadi pengurangan jumlah siswa yang mendapat nilai sangat baik dari $1,72 \%$ menjadi $1,04 \%$, tetapi jumlah siswa yang mendapat nilai baik mengalami peningkatan dari 93,97\% menjadi 97,40\% berdasarkan angaka statistik tersebut dapat disimpulkan bahwa setelah dilaksanakan KTSP tidak terjadi peningkatan yang besar dan penurunan yang berarti, hai ini menandakan bahwa tidak ada perubahan kepribadian antara sebelum dan sesudah dilaksanakannya KTSP.

\section{Kelulusan Siswa}

Berdasarkan hasil observasi arsip sekolah diketahui bahwa kelulusan siswa di SMPN 37 Jakarta adalah $100 \%$ dan siswa yang melanjutkan ke tingkat SMU Negeri secara rinci diperlihatkan pada tabel berikut:

Tamatan dan Melanjutkan ke Tingkat SMU Negeri

\begin{tabular}{|c|c|c|c|c|}
\hline \multirow{2}{*}{$\begin{array}{c}\text { Tahun } \\
\text { Pelajaran }\end{array}$} & \multicolumn{2}{|c|}{$\begin{array}{c}\text { Tamatan } \\
(\%)\end{array}$} & \multicolumn{2}{c|}{$\begin{array}{c}\text { Siswa melanjutkan Ke } \\
\text { SMTA Negeri (\%) }\end{array}$} \\
\cline { 2 - 5 } & Jumlah & Target & Jumlah & $\begin{array}{c}\text { Targe } \\
\text { t }\end{array}$ \\
\hline $2001 / 2002$ & 100 & 100 & 82,43 & 90 \\
\hline $2002 / 2003$ & 100 & 100 & 80,51 & 80 \\
\hline $2003 / 2004$ & 100 & 100 & 80,02 & 80 \\
\hline $2005 / 2006$ & 100 & 100 & 80,44 & 90 \\
\hline $2006 / 2007$ & 100 & 100 & 80,54 & 80 \\
\hline
\end{tabular}


Berdasarkan data tersebut dapat diketahui bahwa kelulusan siswa dan yang melanjutkan ke SMTA Negeri sebelum dan sesudah KTSP tidak ada perubahan.

\section{PENUTUP}

\section{Kesimpulan}

1. Kurikulum yang disusun telah sesuai dengan landasan dan petunjuk yang telah ditetapkan, Visi Misi, Struktur kurikulum, pengaturan beban belajar, ketuntasan belajar, kalender pendidikan telah sesuai dengan landasan hukum yang berlaku.

2. Kebijakan dan keputusan pejabat sekolah berkenaan dengan persiapan KTSP telah memadai dalam mendukung terlaksananya Kurikulum Tingkat Satuan Pendidikan (KTSP).

3. Kompetensi guru cukup memadai dalam mendukung terlaksananya KTSP, arti cukup memadai berarti masih perlu ditingkatkan.

4. Informasi, prasarana dan biaya telah memadai dalam mendukung terlaksananya KTSP.

5. Persyaratan Pelaksanaan Proses Pembelajaran Perlu dipebaiki dalam beberapa hal agar lebih sesuai dengan standar proses (mengacu pada Peraturan Menteri Pendidikan Nasional No 41 Tentang Standar Proses proporsi jumlah rombongan belajar pada SMP Negeri 37 Jakarta $100 \%$ tidak sesuai dengan Standar Proses.

6. Pelaksanaan Proses Pembelajaran telah sesuai dengan standar proses (mengacu pada Peraturan Menteri Pendidikan Nasional No 41 Tentang Standar Proses).

7. Prestasi belajar siswa setelah proses pembelajaran mengalami peningkatan.

8. Kepribadian siswa setelah proses pembelajaran tidak mengalami peningkatan.

\section{Implikasi}

1. Kurikulum Tingkat Satuan Pendidikan (KTSP) merupakan kurikulum yang mengakomodir keragaman potensi daerah dan potesi peserta didik, namun demikian pihak sekolah sebagai lembaga yang mengemban penyusunan Kurikulum harus secara jeli dan serius memperhatikan potensi-potensi dan sumber-sumber yang dimiliki sehingga tujuan KTSP benar-benar dapat tercapai.

2. Kurikulum Tingkat Satuan Pendidikan (KTSP) memberikan kebebasan kepada sekolah untuk menyusun kurikulum sesuai Standar Isi dan Standar Kompetensi Lulusan yang telah ditetapkan, untuk itu maka kurikulm yang disusun dapat lebih fleksibel mengikuti kemampuan sumber daya manusia, kemampuan pembiayaan sehingga secara aktual kurikulum yang disusun dapat terlaksana. 
3. Kurikulum Tingkat Satuan Pendidikan (KTSP) dalam proses pembelajaran memberikan keleluasaan Guru untuk menentukan materi dan penekanan sesuai dengan kondisi lingkungan dan kemampuan siswa yang bertujuan untuk mempertajam kompetensi siswa dalam bidang ilmu bersangkutan, dengan demikian keberadaan kualitas dan profesionalitas guru sangat menentukan kebeberhasilan KTSP, Untuk itu maka peningkatan kualitas dan profesionalitas guru harus menjadi agenda kegiatan sekolah yang rutin dan berkesinambungan.

4. Titik perbedaan Tujuan Model KTSP dengan Model Kurikulum lainnya adalah tujuan program yang bermuara pada keragaman potensi daerah serta siswa dan tuntutan pembangunan Daerah serta Nasional sehingga sekolah sebagai alat pendidikan Nasional benar-benar dapat mencetak sumber daya manusia yang mampu mengembangkan sumber daya alam yang dimiliki oleh daerah bersangkutan.

\section{Saran}

1. Kepada pimpinan sekolah dan stafnya untuk senantiasa melakukan pengembangan struktur kurikulum terutama pada tujuan mengantarkan peserta didik sehingga mampu mengalola potensi daerah yang dimiliki.

2. Kepada para guru agar selalu mengembangkan metode pembelajaran yang inovatif sehingga dapat mengaktifkan potensi siswa.

3. Perlu disusun suatu agenda kegiatan rutin dan berkesinambungan berupa pelatihan atau studi kepada guru sehingga mampu meningkatkan kemampuan guru dalam keilmuan yang dimiliki atau teknik mendidik.

4. Perlu dikembangkan strategi dan pendidikan kepribadian secara intensif sehingga peningkatan kepribadian siswa dapat tercapai.

5. Evaluasi ini perlu terus dikembangkan sehingga kebijakan memiliki referensi akurat sehingga ketepatan pengambilan kebijakan dapat diperoleh.

\section{DAFTAR PUSTAKA}

Beauchamp, George A. 1975. Curriculum Theory. Wilmette. Illinois: The Kagg Press.

BSNP. 2006. Panduan Penyusunan Kurikulum Tingkat Satuan Pendidikan Jenjang Pendidikan Dasar dan Menengah. 
Departemen P\&K. 1985.Pendidikan Indonesia dari Jaman ke Jaman. Jakarta:Balai Pustaka,

Dinas Pendidikan Pemerintah Propinsi Daerah Jakarta. 2006.Buku Petunjuk Instrumen Evaluasi Diri.

Lampiran PerMen no24 Th 2006. Tentang Standar ISI

Setiadi, Hari. 2006. Penulisan Proposal dan Tesis Evaluasi Program Pendidikan. Jakarta : PPs UHAMKA.

Sutikno.Mazayanah. 2006. Evaluasi pendidikan konsep dan ap///cas/.Jakarta:UHAMKA Press.

Taba, Hilda. (1962). Curriculum Development Theory and Practice. New York: Macmillan Publishing Co, Inc.

Thaib, Amin. 2005. Standar Supervisi dan Evaluasi Pendidikan Pada Madrasah Aliyah. Jakarta : DitMaPenda Departemen Agama.

Worthern,Blaine R. and James R. Sanders, 1987. Educational Evaluation : Alternative Approaches and Prastical Guidlines. New York: Longman, Inc.

Zakaria, Teuku Ramli. 2006. Evaluasi pendidikan konsep dan aplikasi. Jakarta: UHAMKA Press. 